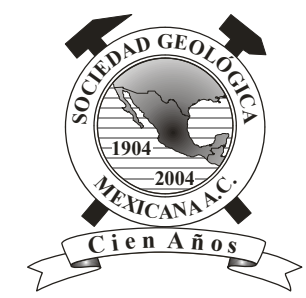

\title{
Submicromorphology of pedogenic carbonate accumulations as a proxy of modern and paleoenvironmental conditions
}

\author{
Alsu M. Kuznetsova ${ }^{1, *}$, Olga S. Khokhlova ${ }^{2}$ \\ ${ }^{1}$ Lomonosov Moscow State University, Moscow, Russia, 119991. \\ ${ }^{2}$ Institute of Physicochemical and Biological Problems of Soil Science RAS, Puschino, Russia, 142290. \\ *alsu25@mail.ru
}

\begin{abstract}
It is likely that the morphology of pedogenic carbonate accumulations (CAs) relates to soil formation conditions and processes. The technique of electron microscopy is especially efficient and applicable to the description of CAs morphology. This method allows estimating the structure and organization of CAs visually and their composition with the X-ray energy dispersive spectrometer for both buried paleosols and surface soils. The relations between submicromorphological features of CAs and conditions of their formation in soil were established: (i) in contrasting climates (alternation of dry and wet seasons), colloform (cryptocrystalline) films are formed; (ii) in dry periods CAs with perfect crystals and sharp borders are formed; (iii) in more humid periods the CAs crystals become irregular with broken faces and holes on surfaces; (iv) needle-shaped calcite crystals are formed in fast-changing water regimes from saturated solutions; (v) perfect crystals grow in quiet conditions from solutions of normal concentration. Submicromorphological studies of the CAs in pedochronosequences can account for trends in changes undergone by soils/paleosols and permit estimation of the general trend of soil evolution.
\end{abstract}

Keywords: Pedogenic carbonate accumulation, buried paleosol, electron microscopy, submicromorphological features, colloform films.

\section{Resumen}

Es probable que la morfología de las acumulaciones de carbonatos (ACs) se relaciona con las condiciones y procesos de formación de suelo. La técnica de microscopia electrónica es especialmente eficiente y aplicable a la descripción de la morfología de ACs. El método permite la estimación de la estructura y la organización de las ACs de manera visual, y de su composición con el espectrómetro de energía dispersiva de rayos X tanto en los paleosuelos sepultados como en los suelos superficiales. Las relaciones entre los rasgos submicromorfológicos de las ACs y las condiciones de su formación en el suelo se establecieron: (i) en climas contrastantes (alternancia de estación seca y húmeda) se forman películas coloformes (criptocristalinas); (ii) en épocas secas se forman cristales perfectos de ACs con bordes agudos; (iii) en épocas más húmedas, los cristales de ACs se vuelven irregulares con caras rotas y hoyos en su superficie; (iv) en regímenes de cambio rápido de agua, se desarrollan cristales de calcita con forma de aguja a partir de soluciones saturadas,; (v) cristales perfectos crecen en condiciones de quietud a partir de soluciones de concentración normal. El estudio de la submicromorfología de las ACs en pedocronosecuencias puede marcar la tendencia de cambio en suelos/paleosuelos y estimar la directriz de la evolución del suelo.

Palabras clave: Acumulación de carbonato pedogenético, paleosuelo sepultado, microscopía electrónica, rasgos submicromorfológicos, películas coloformes. 


\section{Introduction}

Carbonate accumulations (CAs) are the basic pedogenic features in soils and paleosols of arid/semiarid regions of the world. Morphological studies of CAs on different levels of soil (paleosol) mass organization are one of the instruments used to describe and understand soil formation conditions and processes. The use of electron microscopy for reconstruction of paleoenvironments is very important, especially for a detailed morphological investigation.

Nowadays the morphology of CAs on all levels of soil mass organization is described in detail: from macro(nodules, "white-eyes", crust, cutans, etc.) to submicrolevel (thin films, separate crystals and aggregates) (Polyakov, 1989; Kemp, 1995; Becze-Deak et al., 1997; Lebedeva and Ovechkin, 2003; Khokhlova and Kuznetsova, 2002; Khokhlova et al., 2000, 2004; Alonso-Zarza and Tanner, 2006; Srivastava et al., 2007). Sizes of pedogenic CAs vary widely: from a few centimeters to a few microns. From a traditional perspective, the CAs consist of a crystalline matrix with different forms of crystals: prismatic, rhomboidal, needle-like, etc. (Gerasimova et al., 1992; Reheis et al., 1992). Crystals of CAs may be perfect or broken, with traces of etching, dissolution or growth depending on soil formation processes.

The formation of CAs may occur in different ways: precipitation from upward flow of soil solutions in cold dry seasons (Afanasyeva, 1974); chemical precipitation from mineral ground water (Dobrovolskiy, 1961); recrystallization of lithogenic carbonates inherited from parent material (Polyakov, 1989); biogenic processes vital activity of bacteria, fungi, actinomycetes (Wright and Tucker, 1991; Verrecchia and Verrecchia, 1994) and biochemical activity of yeast (Aristovskay, 1980). The CAs in recent soils and Holocene paleosols are mainly formed from calcite, and occasionally from low-magnesium calcite or dolomite (Ovechkin, 1984). More ancient paleosols (Pleistocenic, Carboniferous, Permian-Triassic) have both calcite and aragonite/dolomite accumulations (Wright, 1994; Kuznetsova et al., 2004).

Pedogenic carbonates are an accurate proxy of soil formation and functioning because the morphology of CAs is directly bound up with the processes of dissolutionprecipitation; consequently they contain information about climate and water regime dynamics.

The technique of electron microscopy is especially efficient and applicable to the description of CAs morphology. This method allows visual estimation of the structure and organization of CAs and identification of their composition by means of an X-ray energy dispersive spectrometer. Thus, we can employ it as a universal method for research on both buried paleosols and surface soils.

Hence, the objective of this paper is to show that the submicromorphology of CAs in different soil types is subject to soil conditions, and to understand the possibility of using the submicromorphological features of CAs as a proxy for reconstruction of paleoenvironments. Special attention has been given to the dependence of CAs morphology on the conditions and processes under which soil formation takes place.

\section{Objects and methods}

Different types of CAs are presented and described on the basis of perennial observations in surface soils and buried paleosols, as well as their forming conditions.

The main study objects are CAs formed in different types of soils from different regions of the world. All surface soils and buried paleosols are integrated by two features: the presence of CAs on the macromorphological level of observation and reaction with $10 \% \mathrm{HCl}$. The surface soils and buried paleosols studied herein are the following (classified according to WRB, 2006, but also including the widely known local names):

- Modern soils (Greyic Luvic Phaeozem, Chernozems and Kastanozems) of the forest-steppe and steppe zones of Russia;

- Modern surface soils and buried Holocene paleosols (Chernozems and Kastanozems) of the Cis-Ural steppe, Russia;

- Modern surface Chernozems of the Argentinean Pampa, Argentina (locally known as Mollisols) with a carbonate horizon (tosca) underlying a humus horizon and possibly presenting a different stage of pedogenesis.

- Buried Holocene paleosols (Chernozems) of the Northern Caucasus mountain region, Russia;

- Terra Rossa (Calcic Luvisol-Rhodic) from Tunisia on the northern Mediterranean coast;

- Buried Carboniferous paleosols (Calcic and Petrocalcic Gleysols) of the Moscow syneclise, Russia.

The undisturbed freshly fractured internal surfaces of samples were examined with the binocular optical microscope and the scanning electron microscope Jeol JSM-6380LA, equipped with an X-ray energy dispersive spectrometer (EDS, JED-2300). Samples were coated with $\mathrm{Au}$ before analysis in the Eiko-3 ion coater.

\section{Results and discussion}

\subsection{Colloform films}

Electron microscopy allowed the discovery of a new form of CAs - colloform (cryptocrystalline) films (Figure 1a) that develop in conditions of contrasting climate with clearly expressed dry and wet seasons (Kuznetsova and Khokhlova, 2010). These colloform films occurred in a wide number of semiarid/arid soils in different regions of the world. The main peculiarities of colloform film formations are 


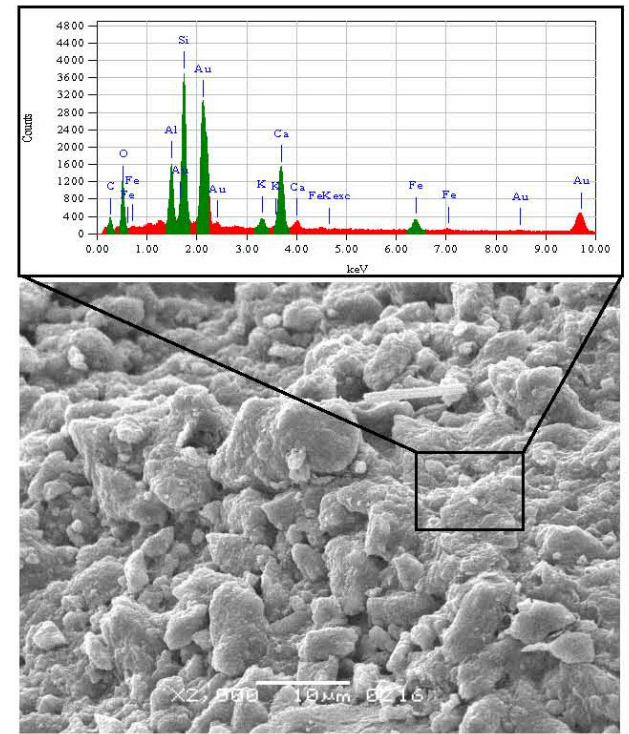

a

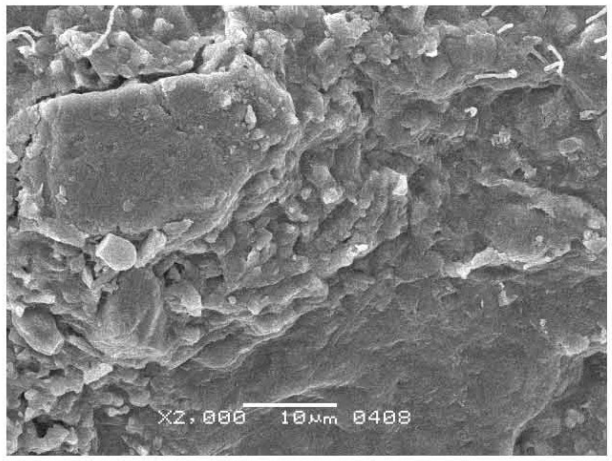

b

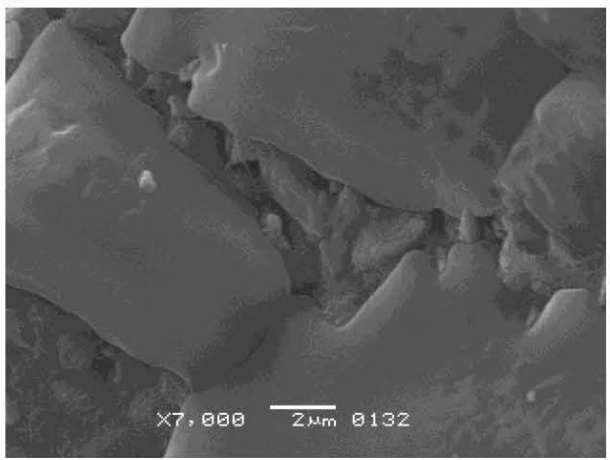

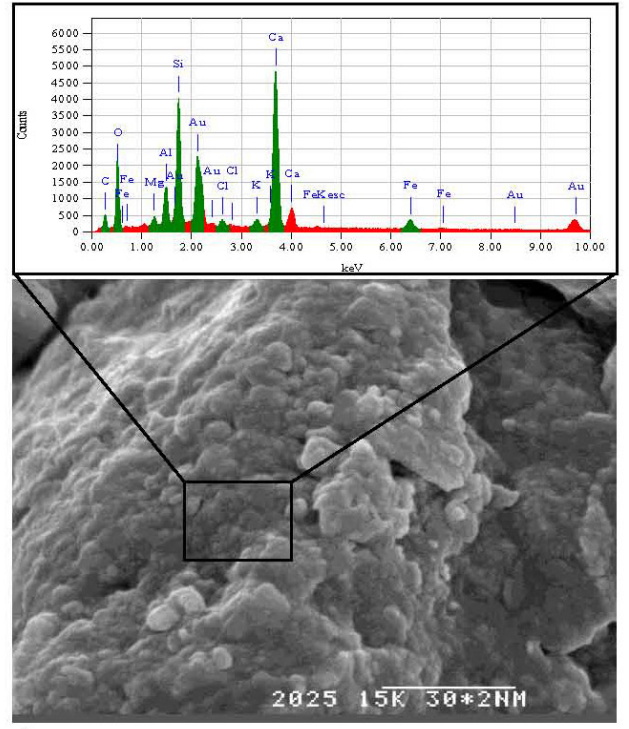

$\mathrm{d}$
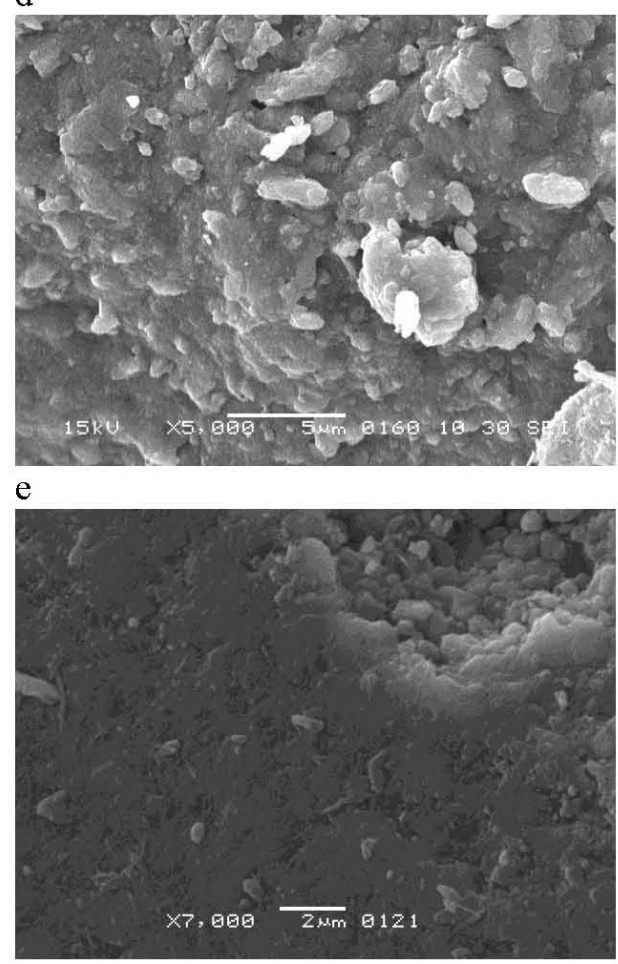

f

Figure 1. Colloform films in different soils and stages of transformation from crystalline carbonate accumulations: a - fragmentary film on aluminosilicate bed (EDS data show elemental composition of sample in the area indicated); $b$ - colloform film fills large and small pores and hollow space; $\mathrm{c}$ - colloform film smoothes surface of the sample from the Terra-Rossa (Northern Tunisia); $d$ - sample from the Southern Chernozem (the Southern Cis-Ural, Russia); e - sample from the Typical Chernozem (the Northern Caucasus, Russia); f - sample from the Calcic paleosol of Carboniferous (the Russian plain).

their smooth surfaces. They may precipitate from colloidal solutions or form in situ after dissolution of crystals. Under arid climatic conditions, colloform films have some growth faces; their thickness is greater than $1 \mu \mathrm{m}$ and they mask a relief of soil matrix. During the humid period, these films become thinner and fragmentary and soil matrix (usually aluminum silicate grains) becomes partly free of the films (Figure 1b). Such genesis is similar to the formation of cryptocrystalline sinter minerals in caves (Hill and Forti, 1997; Stepanov, 1998).

In soils and paleosols from different regions, including the Terra Rossa from Tunisia; Chernozems from Southern Cis-Ural, Russia and Northern Caucasus, Russia; and a Carboniferous Calcic Gleysol from the Russian plain (Figures 1c, 1d, 1e, 1f, respectively), the colloform film has similar morphological features. Its surface is smooth, 
sometimes with semi-dissolved crystals. Stages of colloform structure formation were studied in soil chronosequences or in soils formed in different conditions (Figures 1c, 1d, 1e, 1f). First, the thin fragmentary film is formed on an aluminosilicate bed with imperfect crystals on the surface, (Figure 1a). The substantial content reflects that the thickness of the colloform film is less than $1 \mu \mathrm{m}-$ depth of EDS analysis. Then the colloform films infill large and small pores and hollow spaces, smoothing the surface of the sample (Figures 1b, 1c). The film thickness increases according to data from the EDS spectrum. The final stage is continuous thickening of the colloform film that hides the aluminosilicate matrix (Figures 1d, 1e, 1f).

\subsection{Calcic accumulations of different genesis}

Biogenic and chemogenic calcic accumulations (calcite and gypsum) were found in the Chernozems (Mollisols) of the Argentinean Pampa (the southeast part of the Buenos Aires province). The submicromorphology of pedogenic calcic accumulations has been studied, focusing on their distribution down through the soil profile and the mechanism of formation. In the undisturbed samples the continuous carbonate colloform films (Figure 2a) and carbonate tubules (Figure 2b) are visible with the scanning electron microscope. The origin of these carbonate accumulations is chemical: they were formed by processes of dissolutionprecipitation of calcite from the underlying petrocalcic horizon.

Spheroid gypsum accumulations located on the border of the humic and illuvial horizons are most likely biogenic. We suggest these spheroid gypsum accumulations are the result of crystalline "crusts" formed around and by spherical cyanobacterial colonies (Figures 2c, 2d). These gypsum accumulations reflect seasonal dynamics of formation: they are formed and exist in the soil profile during dry seasons only, whereas in wet seasons they are dissolved and disappear from the Chernozem profile.

\subsection{Morphology of crystalline CAs as proxy of water regime}

A relation between the forms of crystalline CAs (size and shape of crystals) and conditions of their formation has been established. In dry periods, CAs with perfect crystals and sharp borders were found (Figure 3). Perfect crystals grow in undisturbed conditions without abrupt changes from solution of normal concentration (Figure 3a), confirmed by the EDS spectrum. In more humid periods, calcite crystals become irregular with broken faces and holes (Figure 3b). On the other hand, the formation and transformation of carbonate nodules are reflected by their morphology: perfect
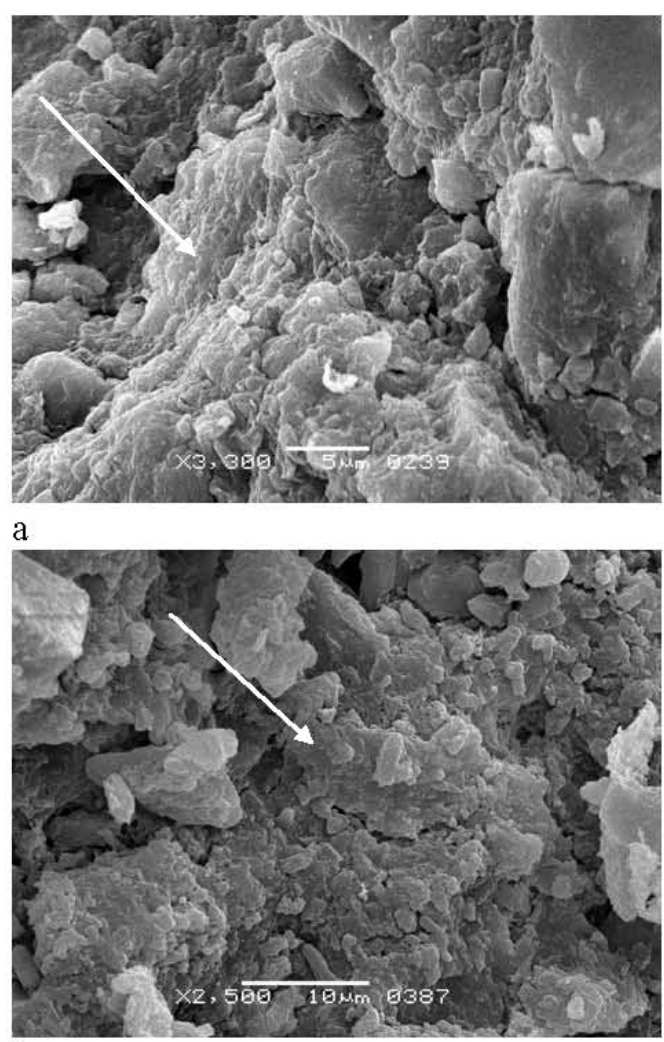

b

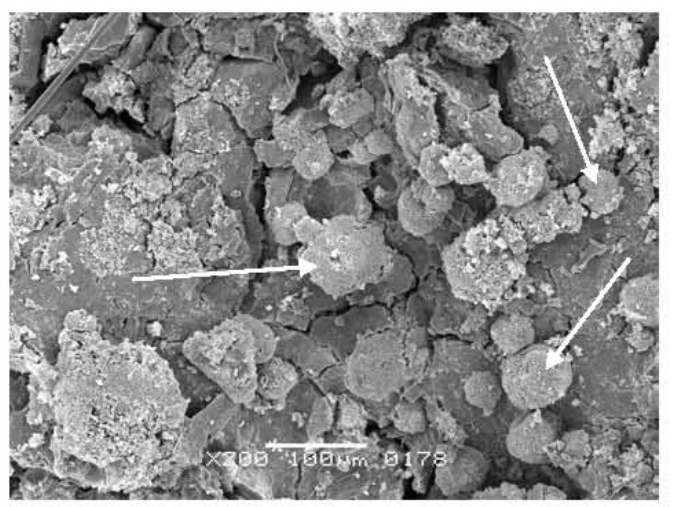

$\mathrm{c}$

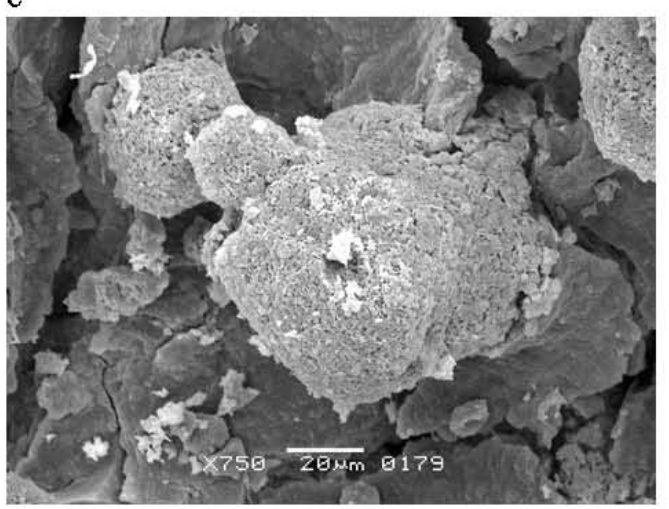

d

Figure 2. SEM-photos of pedogenic accumulations in the Mollisols of the Argentinean Pampa: $a, b$ - chemogenic carbonate colloform films (marked by arrows); c, d-gypsum biogenic spheroid accumulations (some are marked by arrows). 


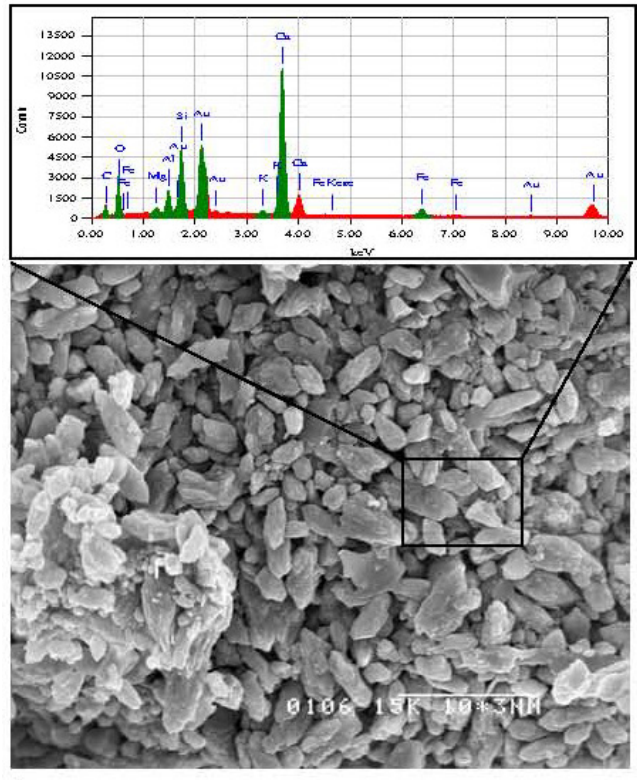

a

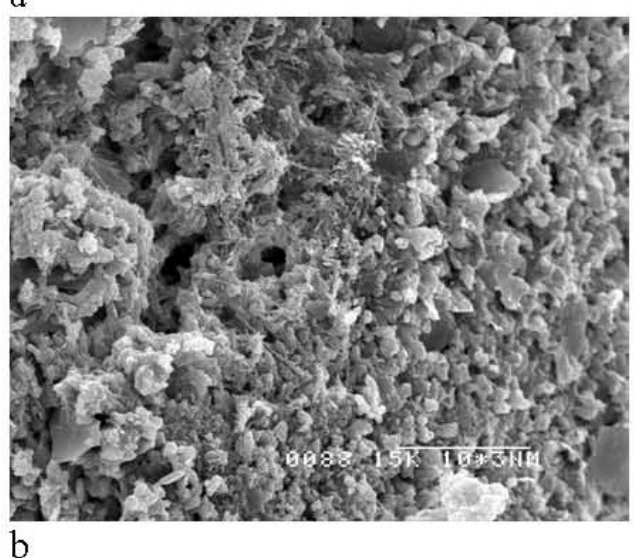

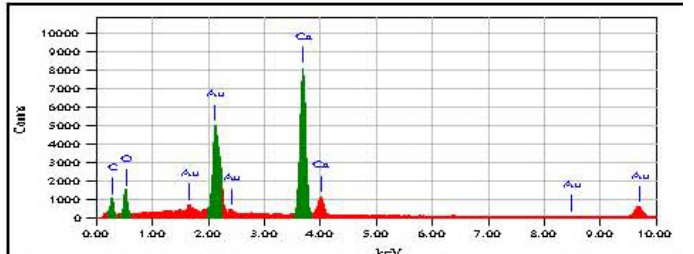

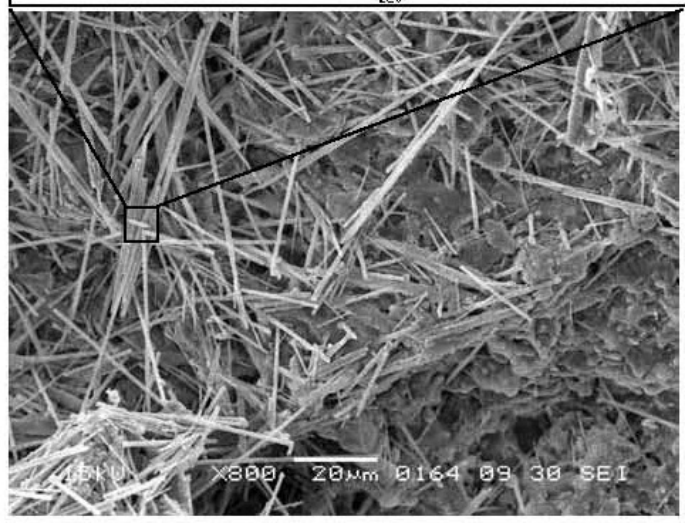

$\mathrm{c}$

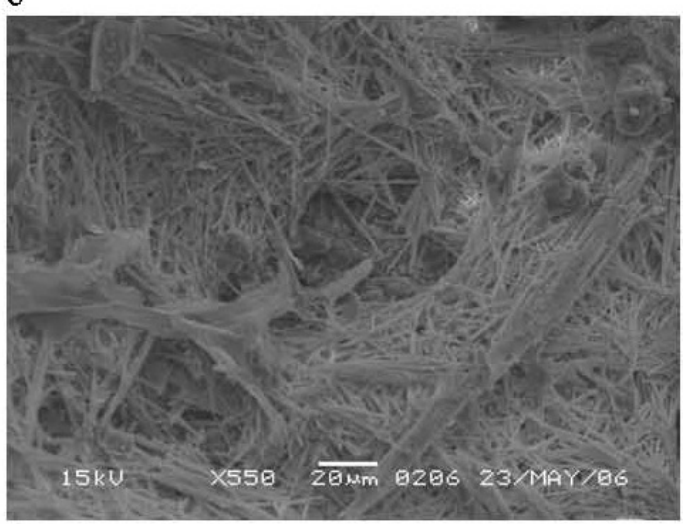

d

Figure 3. SEM-photos and microprobe analyses (marked by squares) of CAs; forms of crystals depend on formation conditions: a - perfect crystals from solution of normal concentration were formed in calm conditions (arid epoch); b - calcite crystals become broken and etched in more humid conditions; $\mathrm{c}$ - needle-shaped calcite from saturated solutions; $\mathrm{d}$ - needle-shaped crystals re-crystallize in more humid conditions.

crystals of the nodules are an indicator of arid conditions (Khokhlova and Kuznetsova, 2004), whereas the CAs with imperfect crystals, unclear borders and shapes, are formed in humid periods (Khokhlova and Kuznetsova, 2002). Needle-shaped calcite forms in fast-changing water regimes from saturated soil solutions, for example, in the buried paleosols of the Northern Caucasus, Russia (Figures 3c, 3d) (Khokhlova et al., 2009).

Submicromorphology of CAs is related primarily with water and temperature regimes of soils. Thus, stages of climatic changes and soil evolution may be established using morphology of CAs.

\subsection{Changing of carbonate accumulation morphology during agrogenic soil evolution}

Trend, rate and stages of CAs transformation during agricultural practices in a Greyic Luvic Phaeozem were established from the submicromorphological analysis. The Greyic Luvic Phaeozem evolves to the Greyic Chernozem with increased content of carbonate in the profile. CAs and carbonate horizons evolve in two stages: after 100 years of agricultural impact the carbonates move most actively, and the conditions of dissolution-precipitation are most dynamic. Then, the structure of CAs in the upper carbonate horizons becomes more colloform and in the lower carbonate horizons calcite is more segregated and crystallomorphic (Figure 4).

\section{Conclusions}

Based on the results obtained, we conclude that the submicromorphology of CAs may be useful for reconstruction of recent climatic conditions as well as paleoenvironments. In this work the relations between 

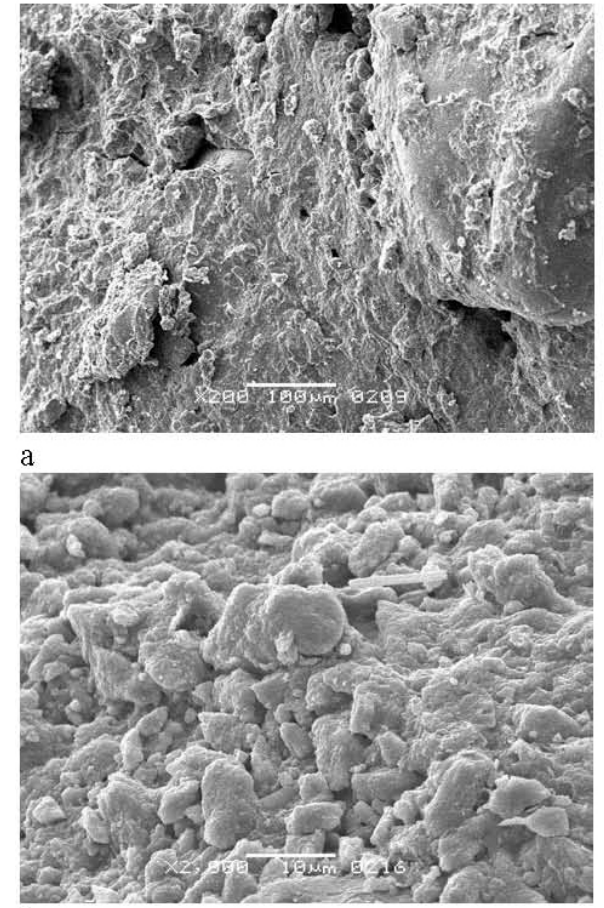

b

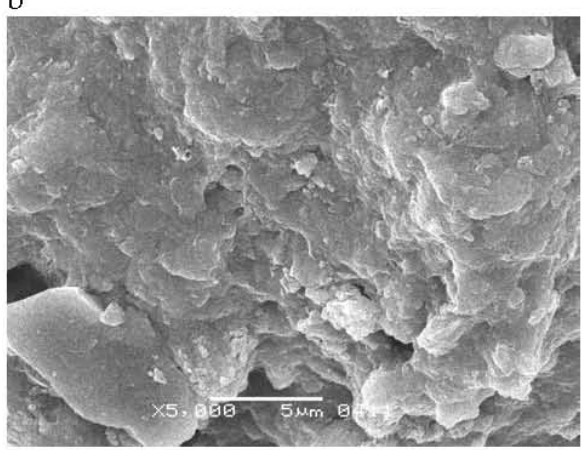

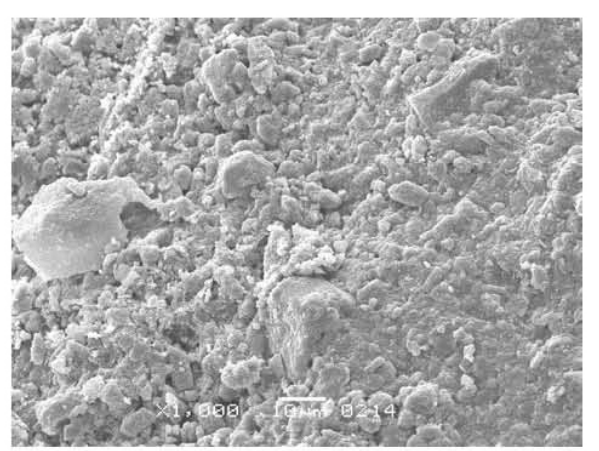

d

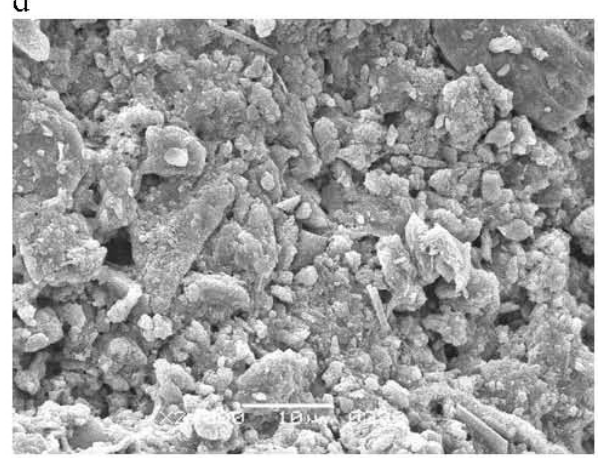

e

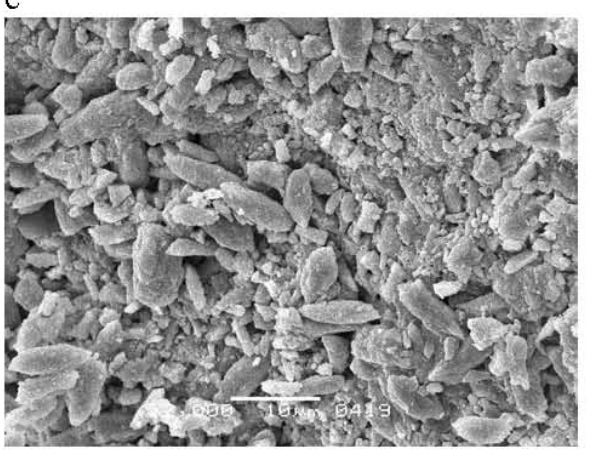

$\mathrm{f}$

Figure 4. Changes of CAs during agroevolution: a - the upper horizon of virgin soil (the Grey-Luvic Phaeozem); $\mathrm{b}$ - the upper horizon of 100 year old field (the Grey-Luvic Phaeozem agrogenic gleyic); $\mathrm{c}$ - the upper horizon of 150 year old field (the Chernozem podzolic agrogenic); $\mathrm{d}$ - the lower horizon of virgin soil (the Grey-Luvic Phaeozem); e - the lower horizon of 100 year old field; f - the lower horizon of 150 year old field.

forms of CAs and the soil conditions under which they are formed were established:

- in conditions of contrasting climate, the colloform (cryptocrystalic) films are formed;

- in dry periods, the CAs with beautiful perfect crystals and sharp borders are formed;

- in more humid periods, the CAs crystals become irregular with broken faces and holes;

- needle-shaped calcite crystals are formed in fastchanging water regimes from saturated solutions;

- perfect crystals grow in quiet conditions from solutions of normal concentration.

Investigation of the submicromorphology of CAs in pedochronosequences can account for trends in soil/paleosol changes, allowing us to estimate the general trend of soil evolution and even the rate and dynamics of soil formation processes.

\section{References}

Afanasyeva, E.A., 1974, Salt profile of Chernozems and its formation in Chernozems of USSR: Moscow, Kolos, 1, 145-156. (in Russian).

Alonso-Zarza, A.M., Tanner, L.H., 2006, Paleoenvironmental record and applications of calcretes and palustrine carbonates: Boulder, Colorado, U.S.A., Geological Society of America Special Paper, $416,248 \mathrm{p}$.

Aristovskay, T.V., 1980, Microbiology of soil forming processes: Moscow, Nauka, 187 p. (in Russian).

Becze-Deàk, J., Langohr, R., Verrecchia, E.P., 1997, Small scale secondary $\mathrm{CaCO}_{3}$ accumulations in selected sections of the European loess belt. Morphological forms and potential for paleoenvironmental reconstruction: Geoderma, 76, 221-252.

Dobrovolskiy, V.V., 1961, Carbonate accumulations in meadow paleosols of the southern part of the Boreal zone: Moscow, Scientific reports of high school, Biological Sciences, 3, 180-184. (in Russian).

Gerasimova, M.I., Gubin, S.V., Shoba, S.A., 1992, Soil micromorphology of natural zones of USSR: Puschino, Moscú, ONTI PNC RAS, 215 p. (in Russian). 
Hill C., Forti, P., 1997, Cave minerals of the world: Huntsville, Alabama, National Speleological Society, $380 \mathrm{p}$.

Kemp, R.A., 1995, Distribution and genesis of calcitic pedofeatures within a rapidly aggrading loess-paleosol sequence in China: Geoderma, 65, 303-316.

Khokhlova, O.S., Kuznetsova, A.M. 2002, Morphology of pedogenic carbonate accumulations by changing environmental conditions in soils dry-steppe zones of the Southern Cis-Ural: Eurasian Soil Science, 11, 1371-1379.

Khokhlova, O.S., Kuznetsova, A.M., 2004, Carbonate accumulation morphology in a soil chronosequence in the southern Pre-Ural, Russia: Significance for Holocene paleoenviromental reconstruction: Revista Mexicana de Ciencias Geologicas, 21, 185-194.

Khokhlova, O.S., Sedov S.N., Khokhlov, A.A., 2000, Carbonate status of modern soils and paleosols of the Sunzhenskaya depression in the Northern Caucasus: Eurasian Soil Science, 4, 416-426.

Khokhlova, O.S., Kuznetsova, A.M., Khokhlov, A.A., Oleynik, S.A., Sedov, S.N., 2004, About genesis of carbonate concentrations ("white-eyes" and hard nodules) an example of the Chernozem mesocatena in the Southern Pre-Ural: Eurasian Soil Science, 7, 773-780.

Khokhlova, O. S., Kuznetsova, A.M., Khokhlov, A.A., 2009, Transformation pathway of carbonate pedofeatures based on their micromorhology and carbon isotope data in the Northern Caucasus region, Russia: Journal of Mountain Science, Micromorphological Studies in Soil Science, 6, 139-146.

Kuznetsova, A.M., Khokhlova, O.S., 2010, Morphology of carbonate accumulations in soils of various types: Lithology and Mineral Resources, 45, 89-100.

Kuznetsova, A.M., Kuznetsov, P.V., Sedov, S.N., Targulian, V.O., Inozemcev, S.A., Kabanov, P.B., 2004, Buried paleosols of the Early and Middle Carboniferous in Moscow region: MSU Bulletin, Soil Science, 2, 22-30.

Lebedeva, I.I., Ovechkin, S.V., 2003, Carbonate profile of the EasternEuropean Chernozems: Soil science, problems and solutions: Moscow, Soil Science Institute, scientific papers, 34-54. (in Russian).
Ovechkin, S.V., 1984, Genesis and mineralogy of carbonate accumulations in the Chernozems, Ukraine and Zavolzhie: Soil and soil cover of forest and steppe zones of USSR and their rational use: Moscow, Soil Science Institute, scientific papers, 184-189. (in Russian).

Polyakov, A.N., 1989, Micromorphological investigation of calcite in Chernozems of the European part of Russia: Eurasian Soil Science, 2, 79-86. (in Russian).

Reheis, M.C., Sowers, J.M., Taylor, E.M., McFadden, L.D., Harden, J.W., 1992, Morphology and genesis of carbonate soils on the Kyle Canyon fan, Nevada, U.S.A.: Geoderma, 52, 303-342.

Srivastava, P., Singh, A.K., Parkash, B., Singh, A.K., Rajak, M.K., 2007, Paleoclimatic implications of micromorphic features of Quaternary paleosols of NW Himalayas and polygenetic soils of the Gangetic Plains - A comparative study: Catena, 70, 169-184.

Stepanov, V.I., 1998, Structures and textures of mineral aggregates forming in free space of caves: Moscow, Speleology in Russia, 1, 70-91. (in Russian).

Verrecchia, E.P., Verrecchia, K.E., 1994, Needle-fiber calcite; a critical review and a proposed classification: Journal of Sedimentary Research, 64, 650-664.

World Reference Base for soil resources (WRB), 2006, A framework for international classification, correlation and communication: Rome, Food and Agricultural Organization of the United Nations, World Soil Resources Reports, 103, 128 p.

Wright, V.P., 1994, Paleosols in shallow marine carbonate sequences: Earth-Science Reviews, 35, 367-395.

Wright, V.P., Tucker, M.E., 1991, Calcretes: an introduction, in Wright, V.P., Tucker, M.E. (eds.), Calcretes: Oxford, Blackwell Scientific Publications, International Association of Sedimentologists, 2, 1-22.

Manuscript received: November 15, 2010.

Corrected manuscript received: October 10, 2011.

Manuscript accepted: December 12, 2011. 